\title{
Tutkimuksen rikastamisesta mielikuvituksella
}

\author{
Sanna Ryynänen ja Anni Rannikko (toim.) \\ Tutkiva mielikuvitus. Luovat, osallistuvat ja toiminnalliset \\ tutkimusmenetelmät yhteiskuntatieteissä \\ Gaudeamus, Helsinki 2021
}

Tomi Kiilakoski

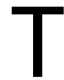
utkimusmenetelmiä käsittelevillä kirjoilla on erityinen asema. Niissä esitellään perusteita tutkimuksen tekemiselle ja kerätään samojen kansien sisään kuvaus jostakin peruslähtökohdasta. Ne kuvaavat siis jollakin tavalla olemassa olevaa tilaa. Tämä tuo niihin konservatiivisen elementin: metodikirjat ovat harvoin radikaaleja avauksia, sillä niiden pitää perustua jo koeteltuihin tutkimuksen tapoihin. Tässä ei ole kuitenkaan koko tarina. Metodikirjat arvottavat, tahtomattaan tai tahtoen. Ne ottavat myös väistämättä kantaa siihen, millaista tutkimuksen pitäisi olla ja millaisia asioita tutkijan on työssään huomioitava. Ne kertovat näkökulmista, joita tekijät haluaisivat lisätä tieteeseen tai häivyttää sieltä. Ne päätyvät usein myös oppikirjoiksi ja toimivat näin sosialisaation välineinä osoittaen, miten tiedettä pitää tehdä ja millainen tutkimus on hyvää. Metodikirjat ovat usein pitkäikäisiä, ja ne ovat harvoin puhetta vain kirjoitusajankohtansa lukijoille. Niissä katsotaan pidemmälle.

Sanna Ryynäsen ja Anni Rannikon toimittama kokoomateos Tutkiva mielikuvitus nostaa jo otsikossaan esille lähtökohtansa. Tavoitteena on puolustaa mielikuvituksen asemaa tutkimuksessa ja osoittaa, että sillä on 
erityistä merkitystä tutkimusta tehtäessä erityisesti ihmistieteissä. Kirjan vastakohdaksi asettuu järkikeskeinen, objektiivisuutta ja tutkijan irrallisuutta tutkittavistaan ihannoiva puhe ja tapa tehdä tiedettä. Tämän tilalla kirjassa esitellään erilaisia menetelmiä kokeileva, ajoittain erehtyvä ja siksi jatkuvaan reflektioon pakotettu, tilanteeseen ihmisenä ihmisten joukkoon tuleva tutkija, joka ei pelkää hyödyntää omaa luovuuttaan. Näin kirja asettuu - jos ei nyt vastahankaan - niin kuitenkin jännitteiseen suhteeseen metodikirjoille ominaiseen varovaisuuteen.

Teoksen eri artikkelit nostavat esiin monia kiinnostavia teemoja ja huomioita. Tarkoitukseni tässä arvioissa on kuitenkin arvioida teosta kokonaisuutena ja katsoa, minkälainen puheenvuoro tieteen tekemisestä se on.

\section{Mielikuvitus tietämisen välineenä}

Mielikuvituksen teema on eri tieteenaloilla nousussa oltuaan muutaman vuosikymmenen taka-alalla. Käsitteellä on pitkänpuoleinen teoria- ja käsitehistoria. Mielikuvitus, imaginaatio, on filosofiassa ollut tieto-opillisen tutkimuksen yksi perinteinen tutkimuskohde. Esimerkiksi skottilaisen valistuksen edustaja, filosofi David Hume erotti mielikuvituksen kaksi ulottuvuutta. Mielikuvituksen voi nähdä kykynä muokata erilaisia ajatuksia, ja näin sillä on yhteys järkeen. Toisaalta sen voi nähdä myös kykynä, jonka avulla ihminen voi luoda hölynpölyä ja hupsutuksia. Kun sanotaan, että jokin on liian mielikuvituksellista, viitataan jälkimmäiseen ulottuvuuteen. Filosofiassa mielikuvitusta pidettiin järkeä täydentävänä elementtinä, jonka avulla voidaan ylittää se, minkä pelkkä laskelmointi tai välitön havainnointi tavoittaa. Mielikuvitus tutkimuksellisen mielenkiinnon kohteena kuihtui toisen maailmansodan jälkeen, mutta viimeaikaisessa keskustelussa se on noussut jälleen esille eri tieteenaloilla. Mielikuvitukselle inhimillisenä kykynä on nähty tässä ajassa jälleen käyttöä, sillä tarvitaan kykyä kuvitella sitä, mitä ei vielä ole. Perinteiset teemat ovat nousseet esille, ja mielikuvitus mietityttää jälleen.

Yhteiskuntatieteilijöille mielikuvitus taitaa olla tuttu lähinnä C. Wright Millsin käsitteestä sosiologinen mielikuvitus. Tällä hän viittasi kykyyn ylittää pelkkä arjessa havaittu elämä. Sosiologista mielikuvitusta omaava osaa nähdä arjessa kohdatun maailman ja yleisten rakenteiden välisen suhteen. Ryynänen ja Rannikko eivät kirjassaan ole niinkään kiinnostuneita käymään teoreettista keskustelua mielikuvituksesta tai paikantamaan omaa näkemystään osaksi olemassa olevia keskusteluja. He ottavat lähtökohdakseen millsiläisen ajatuksen, että mielikuvitus yhdistää näen- 
näisesti ristiriitaisia tasoja, ja lisäävät siihen ripauksen ajattelua, että mielikuvituksessa on kysymys myös luovuudesta ja leikistä.

"Tutkiva mielikuvitus ... on ihmettelyn ja leikillisyyden muistava tutkimuksellinen asenne, jonka avulla voi rakentaa näkemyksellisiä ja yllättäviäkin yhteyksiä monenlaisten ihmisten ja tietojen välille sekä tavoittaa - tai vähintäänkin tavoitella - ihmisyydessä piileviä moninaisia tiedon tasoja."

Tämä näkemys mielikuvituksesta rakentaa teokseen väljän lähtökohdan, jonka mukaan mielikuvitus näkyy usein eri tavoin. Se ilmenee paitsi uteliaisuutena, myös näyttäytyy ihmisten välisissä suhteissa.

\section{Luovuus, toiminnallisuus ja osallisuus}

Teoksen lähtökohta on varsin avoin. Kirjassa ei yritetä rajata tiettyä aluetta vaan esitellään erilaisia tapoja, joilla tutkijat voivat mielikuvitustaan käyttää. Kirja ei aitaa vaan osoittaa laajan maaston, jossa käyskennellä. Toimittajat itse kuvaavat kirjaan valikoituja tekstejä ja niiden tausta-ajattelua huokoiseksi joukoksi erilaisia tutkimusotteita. Näissä tutkimusotteissa on erilaisia tieteenfilosofisia lähtökohtia. Tällöin kartoitetaan väistämättä maaperää, jossa on toisiinsa liittyviä mutta keskenään ristiriitaisiakin lähestymistapoja. Tarkkojen synteesien tekeminen jätetään kunkin lukijan harkinnan varaan.

Kirjassa ei ole kiinnostuttu rajojen vetämisestä. Sen sijaan se osoittaa, että kun lavennetaan näkemystä tieteen tekemisestä, voidaan käsitystä tutkimuksesta rikastaa. Kirja ei väitä korvaavansa tiettyä tieteen tekemisen tapaa. Sen sijaan se asenteellaan täydentää olemassa olevaa kirjallisuutta.

Arvostelijat voisivat kuvata kokoelmaa sisäisesti epäkoherentiksi kokonaisuudeksi, jossa ei ole yhtä ydinviestiä tai selkeätä punaista lankaa. Tämä ei kuitenkaan ole toimittajien tarkoitus. Pikemminkin kirjan asennetta voi hahmottaa filosofi Ludwig Wittgensteinin vertauksella. Wittgensteinin mukaan jonkin asian merkitys ei hahmotu yhdestä yksittäisestä huomiosta. Köydessä ei ole yhtä ainutta säiettä, joka juoksisi läpi köyden, mutta silti köysi on vahva. Köysi pitää. Säikeet liittyvät toisiinsa ja luovat vahvan kokonaisuuden. Tätä Wittgenstein kutsui perheyhtäläisyydeksi. Tällaisena itse luin kirjaa: se pitää sisällään erilaisia toisiinsa liittyviä säikeitä. Säikeiden erilaisuus näkyy paitsi eri luvuissa esiteltyjen menetelmien eroina, myös kirjoitustyylissä ja siinä, kuinka vahvasti kirjoittajat kirjoittavat itsensä ja oman identiteettinsä osaksi tekstiä. Toimittajat ku- 
vaavat, että teokseen valikoiduissa menetelmissä on kyse tunteista, kokemuksista, luovuudesta ja mielikuvituksesta. Tästä syntyvät toisiinsa liittyvät säikeet, jotka juoksevat läpi kirjan kymmenen artikkelin.

Toimittajat nostavat esiin kolme alateemaa, jotka heidän mukaansa yhdistävät mielikuvitusta hyödyntäviä tutkimusmenetelmiä. Näitä ovat luovuus, osallistavuus ja toiminnallisuus. Eri tutkimuksissa ja eri menetelmissä nämä käsitteet painottuvat eri tavoin. Teokseen kootuissa artikkeleissa eri menetelmien edustajat kuvaavat lähtökohtiaan ja ratkaisujaan. Kirjan kirjoittajat ovat kokeneita tutkijoita, jotka edustavat lähinnä yhteiskuntatieteitä mutta myös esimerkiksi kasvatustieteitä. Kirjoittajat ovat kirjoittaneet itsensä tekstiin ja kuvanneet omaa suhdettaan tutkittaviinsa ja aiheisiinsa. Tässä teoksessa ei esiinny passiivissa kirjoittavaa tutkijaa, joka keräisi aineistoaan kuin marjoja mättäästä.

Teos on toimitettu huolellisesti ja pääosin artikkelit ovat nautittavaa luettavaa, hyvää tiedeproosaa. Teosta voi tarkastella esimerkkinä ajatuksesta, jonka mukaan yhteiskuntatutkimus on kielellinen sepitelmä, kuten Juha Suoranta ja Olli Pyyhtinen kiinnostavassa artikkelissaan kaunokirjallisuuden ja yhteiskuntatutkimuksen suhteista muotoilevat. Heidän mukaansa jatkuvat sanavalinnat ja rakennekokeilut ovat väistämätön osa tieteellistä kirjoittamista. Kirja jakautuu johdantoon ja kolmeen osioon, joissa jokaisessa on kolme lukua. Osiot on nimetty kutkuttavasti: Odottamattomia ikkunoita, Kutsuja kuvittelemaan, Yhdessä kohti toimintaa. Erityisesti "Odottamattomia ikkunoita" kuuluu harvoihin otsikoihin, jotka lukiessani huomaan olevani kateellinen ja miettiväni, miksi en ole itse keksinyt näin hyvää tapaa kuvata tutkijan tarvetta osata hämmästyä aineistonsa äärellä.

Kirjan ensimmäinen osio sisältää artikkelit kaunokirjallisuuden käytöstä yhteiskuntatieteissä, autoetnografiasta ja visuaalisista menetelmistä. Toinen osio esittelee eläytymismenetelmän, kirje tulevaisuudesta -menetelmän ja osallistavan kartoituksen. Kolmas osio käsittelee osallistavaa teatteria, muistelutyömenetelmää ja kuljeskelua. Kuten jo suppeasta listauksesta ilmenee, osalla kirjaan valikoiduista menetelmistä on takanaan jo vuosikymmenten historiaa ja tätä kautta syntynyttä keskustelua. Sosiaalipedagogisesti suuntautunut lukija löytää teoksesta paitsi osallistavan teatterin kaltaisia välittömästi avautuvia sosiaalipedagogisia näkökulmia, myös välillisesti asiaan liittyviä henkilökohtaisia sekä yleisiä pohdintoja.

Kirjan kaikki esimerkit käsittelevät laadullista tutkimusta. Monet kirjan teemat tulevat lähelle keskusteluja, joita on käyty post-kvalitatiivises- 
sa tutkimuksessa. Olisikin ollut kiinnostavaa lukea, millaisia yhteyksiä toimittajat tai kirjoittajat hahmottavat näiden metodologiakeskustelujen kanssa. Painotus laadulliseen tutkimukseen on intuitiivisesti perusteltu, onhan vaikkapa taideperusteisissa menetelmissä selkeä yhteys luovuuteen ja mielikuvitukseen. Jos mielikuvitus kuitenkin ymmärretään kykynä nähdä yhteyksiä asioiden välillä ja pohtia ihmisyyden moninaisia muotoja, voi kysyä, onko kirjan kohde rajattu turhan ahtaalle, sillä siinä ei pohdita, miten mielikuvitus ilmenee määrällisessä tutkimuksessa. Tätä pidän onnistuneen teoksen suurimpana kritiikin aiheena: nyt kiinnostavat kysymykset siitä, millä tavoin mielikuvitus voisi ohjata määrällistä tutkimusta ja millaisia metodologisia maisemia tällöin avautuisi, jäävät tarkastelematta. Ajattelen, että tässä on menetetty mahdollisuus sanoa jotakin vielä kiinnostavammin. Onkin toivottavaa, että joku tarttuu tähän teemaan ja jatkaa tältä osin keskustelua mielikuvituksen asemasta tieteessä.

\section{Tutkija käytännössä, käytäntö tutkijassa}

Metodikirjat ovat väistämättä myös tiedepoliittisia puheenvuoroja. $\mathrm{Ne}$ osallistuvat keskusteluun tutkimusta ohjaavista totuusehdoista ja mahdollisuuksien rajoista, joiden puitteissa toimia. Tutkiva mielikuvitus asettuu teoksena puolustamaan moniarvoisuutta. Teoksessa kommentoidaan laajoja teemoja, kuten tieteellisen ja käytännön kentän rajanvedon purkaminen, rationaalisuusharhan ohittaminen, tutkimuksen demokratisoiminen tutkittavien, kanssatutkijoiden tai kansalaisten aseman huomisella sekä tilannekohtaisen harkinnan tärkeyden korostaminen tavalla, joka ei litisty näennäis-rigoröösiä otetta tavoittelevaan "tee näin" -keittokirjametodiikkaan vaan korostaa avoimuutta vaativaa tilanne- ja henkilökohtaista reflektiota. Lisäksi kirjassa korostuu etiikan miettiminen monenlaisten suhteiden ja sitoumusten kautta. Erityisen kiinnostunut kirja on suhteista tutkittaviin ja heidän käytäntöihinsä. Monessa teoksen artikkelissa painopiste on pikemminkin sen pohtimisessa, miten tutkija suhtautuu käytännön kenttään, kuin sen, miten tutkija suuntautuu tiedeyhteisöön. Näiltä osin kirja tuottaa kuvaa tutkijasta toimijana, jolla on useita vastuita tutkimilleen ihmisille ja yhteisöille, joka toimii useiden muiden toimijoiden kanssa ja joka viestii useille eri yleisöille.

Monet metodikirjat luovat kuvan tieteestä harkittuna prosessina, joka on lineaarisesti etenevä, suoraviivainen, etukäteen suunniteltu ja kontrolloitu. Minun on aina ollut hankala sijoittaa omaa toimintaani tutkijana tällaiseen kuvaan. Tästä kuvasta puuttuvat säröt, tutkimuksen aikana ta- 
pahtuvat äkilliset oivallukset, prosessin tunnekuorma ja muiden ihmisten osallistumisen merkitys tutkimukselle. Viihdyin Tutkivan mielikuvituksen parissa sen takia, että se ei ole kiinnostunut luomaan vastakohtia vaan pikemminkin kuvaamaan tutkimuksen tekemisen arkea, jossa korostuvat tilannekohtainen harkinta, tutkittavat yhteisöt, eettiset suhteet ja pyrkimys vahvaan solidaarisuuteen.

Metodikirjat kuvaavat joko vaieten tai suoraan sanoen, millaista on yhteiskuntatieteen tekeminen. Ne ovat väistämättä myös tiedepoliittisia puheenvuoroja. Tutkivassa mielikuvituksessa ei esiinny vakiintuneita menetelmiä hyödyntävä tutkija. Näkökulmana on maailmaan, yhteisöihin ja käytäntöihin kiinnittyvä tutkija, joka ei voi luovuttaa vastuutaan muille. Teos korostaa vahvaa refleksiivisyyttä sekä kykyä asettaa kysymykset ja valita niihin vastaamisen menetelmät uusilla tavoilla. Tämän se tekee hyödyntäen sekä uusia että jo pitkään esillä olleita näkökulmia.

Teoksen korostukset ovat uusia suomalaisessa metodikirjallisuudessa, ainakin jos tarkastellaan yksittäistä menetelmää tai yksittäistä tieteenalaa laajempia, tiedekustantajalta tulevia kirjoja eikä artikkeleita - mikä on oikeastaan eriskummallista, sillä monet kirjan yksittäisistä ajatuksista on esitetty jo aiemmin. Merkillistä. Olisi voinut kuvitella, että tämänkaltainen teos olisi ilmestynyt jo kauan sitten. 